\title{
Use of Natural Products on the Control of Aspergillus flavus and Production of Aflatoxins In Vitro and on Tomato Fruit
}

\author{
Mario Alberto Segura-Palacios ${ }^{1}$, Zormy Nacary Correa-Pacheco ${ }^{2} \mathbb{D}$, Maria Luisa Corona-Rangel ${ }^{2}$, \\ Ollin Celeste Martinez-Ramirez ${ }^{1}$, Dolores Azucena Salazar-Piña ${ }^{1}$ (D), Margarita de Lorena Ramos-García ${ }^{1, *}$ \\ and Silvia Bautista-Baños ${ }^{2, *}$
}

1 Facultad de Nutrición, Universidad Autónoma del Estado de Morelos, Calle Iztaccihuatl S/N, Col. Los Volcanes, Cuernavaca C.P. 62350, Mexico; mario.ln9424@gmail.com (M.A.S.-P.); ollin.martinez@uaem.edu.mx (O.C.M.-R.); azucena.salazar@uaem.mx (D.A.S.-P.)

2 Centro de Desarrollo de Productos Bióticos, Instituto Politécnico Nacional, Carretera Yautepec-Jojutla, km. 6.8, San Isidro, CEPROBI 8, Yautepec C.P. 62731, Mexico; zcorreap@ipn.mx (Z.N.C.-P.); mlcr7@hotmail.com (M.L.C.-R.)

* Correspondence: margarita.ramosg@uaem.edu.mx (M.d.L.R.-G.); sbautis@ipn.mx (S.B.-B.)

check for updates

Citation: Segura-Palacios, M.A.; Correa-Pacheco, Z.N.; Corona-Rangel, M.L.; Martinez-Ramirez, O.C.; Salazar-Piña, D.A.; Ramos-García, M.d.L.; Bautista-Baños, S. Use of Natural Products on the Control of Aspergillus flavus and Production of Aflatoxins In Vitro and on Tomato Fruit. Plants 2021, 10, 2553. https:// doi.org/10.3390/plants10122553

Academic Editors: Jesús Martín-Gil, Vicente Gonzalez Garcia and Pablo Martín-Ramos

Received: 19 October 2021

Accepted: 18 November 2021

Published: 23 November 2021

Publisher's Note: MDPI stays neutral with regard to jurisdictional claims in published maps and institutional affiliations.

Copyright: (c) 2021 by the authors. Licensee MDPI, Basel, Switzerland. This article is an open access article distributed under the terms and conditions of the Creative Commons Attribution (CC BY) license (https:/ / creativecommons.org/licenses/by/ $4.0 /)$.

\begin{abstract}
Aspergillus flavus affects fresh and dry fruit and vegetable products, and its toxic metabolites, namely aflatoxins, cause serious damage in humans. The objective of this research study was to evaluate the effect of commercial natural products as well as edible and nanostructured chitosan coatings on the development of $A$. flavus and on the production of aflatoxins in vitro and in tomato. Treatments were as follows: chitosan $1 \%$, chitosan coating, chitosan nanostructured coating, Citrocover $1 \%$ (citrus seed extract), Resinadher $0.5 \%$ (pine resin extract), mancozeb $2 \%$, and water. The variables were as follows: halo inhibition, spore production, and aflatoxins content. In fruit, the following were evaluated: disease incidence, mycelial growth, and aflatoxin production. An ANOVA (Tukey: $p<0.05$ ) was used. In vitro results showed that Citrocover and Resinadher reduced sporulation $\left(0.2\right.$ and $0.9 \times 10^{5}$ spores $\mathrm{mL}^{-1}$, respectively), while chitosan inhibited the production of aflatoxins. With Resinadher and Citrocover, tomato fruit had the lowest incidence, mycelial growth, and aflatoxin production with corresponding values of $0 \%, 0.0 \mathrm{~cm}^{2}$, and $0.95 \mathrm{ppb}$, respectively, and $7 \%, 0.2 \mathrm{~cm}^{2}$, and $1.77 \mathrm{ppb}$, respectively. The use of Citrocover and Resinadher could be a viable alternative to decrease the development of $A$. flavus in tomato fruit.
\end{abstract}

Keywords: mycotoxins; coatings; nanoparticles; chitosan; citrus seed extract; pine resin extract

\section{Introduction}

Tomato is a perishable fruit and can be contaminated by microorganisms mainly during storage. This is due to the high storage temperatures, increase in relative humidity, and increase in contact with fruit contaminated with microorganisms. The fungi Alternaria alternata, Rhizopus stolonifer, Colletotrichum gloeosporiodes, and Aspergillus flavus can contaminate tomatoes during storage, causing physical damage to the fruit. Aspergillus flavus, in addition to causing physical damage to the fruit, also produces toxic secondary metabolites for the human body called aflatoxins [1]. The consumption of aflatoxins has been confirmed to have carcinogenic, toxic, and mutagenic activity in humans and animals [2,3].

Many papers have reported the contamination of $A$. flavus with products such as corn, peanuts, pistachios, Brazil nuts, cotton seeds, grated dried coconut, sunflower seeds, soybeans, and nuts [4]. However, its presence in fresh fruit and vegetables has recently been reported. Buchanan et al. [5] carried out an investigation in figs contaminated by A. flavus and reported the presence of aflatoxins in all the ripening stages of the fruit, in which the concentrations were higher when the fruit was fully ripe $(28 \mu \mathrm{g} / \mathrm{g}$ of fruit). Additionally, Baiyewu et al. [6] reported the presence of $A$. flavus and aflatoxins in papaya fruit, especially in those showing symptoms of microorganisms' infection, while Maroutti [7] reported the 
identification of the fungi $A$. flavus and A. parasiticus as well as the presence of aflatoxins in fresh tomato fruit and by-products (pulp, paste, purée, ketchup, dehydrated tomatoes, and dried tomatoes preserved in oil).

Chemical fungicides have been mainly used to reduce the development of phytopathogenic fungi in tomatoes; however, some can be neurotoxic, genotoxic, teratogenic, and mutagenic, and can affect human health [8]. The application of these products, as well as the residues that remain in food, seriously affect the health of the people consuming them [9]. The collateral effects of pesticides have led to the need to evaluate new natural, biodegradable, and safe alternative applications for fresh tomato that can satisfactorily control the growth of the fungus $A$. flavus and hence avoid the development of aflatoxins. Among the control methods based on natural products with fungicidal properties to reduce contamination by these fungi [10-15], chitosan (solution, chitosan coating, and chitosan nanoparticles) and extracts of plant species (citrus and pine resin) have been used. However, there is little research on the control of $A$. flavus and its production of aflatoxins in tomato fruit. At present, there are commercial products based on citrus extract and pine resin on the market that have not been evaluated to control the development of $A$. flavus and could be an alternative for future application by producers of Morelos, México.

The objective of this research study was therefore to evaluate the effect of various natural compounds based on chitosan and plant extracts on the development of $A$. flavus in vitro and on tomato during a given storage period.

\section{Results}

\subsection{In Vitro}

In the in vitro studies, no significant statistical differences were observed between the treatments evaluated on day seven of incubation. However, the fungus treated with Citrocover showed statistical differences $(p<0.05)$ from the control $\left(10.4,4.2\right.$, and $\left.3.5 \mathrm{~cm}^{2}\right)$ after four, five, and six days of incubation, respectively (Table 1). Regarding the sporulation, the treatments that notably showed less sporulation $(p<0.05)$ were Citrocover and Resinadher $\left(0.2\right.$ and $0.9 \times 10^{5}$ spores $\mathrm{mL}^{-1}$, respectively; Table 2$)$. The chitosan coating did not show aflatoxin production (0.0). Other treatments that presented low aflatoxin production values were Mancozeb, chitosan, and Citrocover $(0.09,0.10$, and $0.13 \mathrm{ppb}$, respectively), while in the control, the aflatoxin production was $1.21 \mathrm{ppm}$ (Table 2).

Table 1. Inhibition halo of $A$. flavus treated with different natural products during seven days incubation in the in vitro study.

\begin{tabular}{|c|c|c|c|c|}
\hline \multirow{3}{*}{ Treatment } & \multicolumn{4}{|c|}{ Halo of Inhibition $\left(\mathrm{cm}^{2}\right)(x \pm$ S.D. $)$} \\
\hline & \multicolumn{4}{|c|}{ Days of Incubation } \\
\hline & 4 & 5 & 6 & 7 \\
\hline Citrocover & $10.4 \pm 4.4^{\mathrm{b} *}$ & $4.2 \pm 5.1^{b}$ & $3.5 \pm 4.7^{b}$ & $3.0 \pm 4.5^{\mathrm{a}}$ \\
\hline Resinadher & $5.4 \pm 5.0 \mathrm{ab}$ & $2.6 \pm 2.1^{\mathrm{ab}}$ & $2.6 \pm 2.4^{\mathrm{ab}}$ & $2.6 \pm 2.4^{\mathrm{a}}$ \\
\hline Chitosan & $0 \pm 0^{\mathrm{a}}$ & $0 \pm 0^{\mathrm{a}}$ & $0 \pm 0^{\mathrm{a}}$ & $0 \pm 0^{\mathrm{a}}$ \\
\hline Chitosan coating & $0 \pm 0$ & $0 \pm 0^{\mathrm{a}}$ & $0 \pm 0^{\mathrm{a}}$ & $0 \pm 0^{\mathrm{a}}$ \\
\hline Chitosan nanoparticles & $0 \pm 0^{\mathrm{a}}$ & $0 \pm 0^{\mathrm{a}}$ & $0 \pm 0^{\mathrm{a}}$ & $0 \pm 0^{\mathrm{a}}$ \\
\hline Mancozeb & $2.6 \pm 1.3^{\mathrm{ab}}$ & $2.6 \pm 1.5^{\mathrm{ab}}$ & $1.1 \pm 0.1^{\mathrm{ab}}$ & $0.9 \pm 0.15^{\mathrm{a}}$ \\
\hline Water & $0 \pm 0^{\mathrm{a}}$ & $0 \pm 0^{\mathrm{a}}$ & $0 \pm 0^{\mathrm{a}}$ & $0 \pm 0^{\mathrm{a}}$ \\
\hline
\end{tabular}

* Means followed by the same letter are not significantly different $(p<0.05)$ determined by Tukey's multiple test.

\subsection{In Situ}

The fruit that presented the lowest mycelial growth and incidence of $A$. flavus at the end of storage were those treated with Resinadher $(0.0 \mathrm{~cm}$ and $0 \%$, respectively) and Citrocover $(0.2 \mathrm{~cm}$ and $7 \%$, respectively). Both treatments were statistically different $(p<0.05)$ compared with the fruit treated with water $(1.9 \mathrm{~cm}$ and $87 \%$; Table 3$)$. The remaining treatments showed a decrease in the fungal growth; however, they were statistically similar to the control. 
Table 2. Sporulation and production of the aflatoxins of $A$. flavus treated with different natural products after seven days incubation in the in vitro study.

\begin{tabular}{ccc}
\hline Treatment & $\begin{array}{c}\text { Sporulation } \\
\left(\mathbf{1 0} \mathbf{5}^{\mathbf{S}} \text { Spores } \mathbf{~ m}^{-\mathbf{1}}\right)\end{array}$ & $\begin{array}{c}\text { Production of Aflatoxins } \\
\mathbf{( p p b )}\end{array}$ \\
\hline Citrocover & $0.2 \pm 0^{\mathrm{a} *}$ & $0.13 \pm 0.16^{\mathrm{a}}$ \\
Resinadher & $0.9 \pm 0.02^{\mathrm{a}}$ & $0.29 \pm 0.25^{\mathrm{ab}}$ \\
Chitosan & $4.7 \pm 0.6^{\mathrm{b}}$ & $0.10 \pm 0.08^{\mathrm{a}}$ \\
Chitosan coating & $14.5 \pm 4.8^{\mathrm{cd}}$ & $0.00 \pm 0.00^{\mathrm{a}}$ \\
Chitosan nanoparticles & $19.7 \pm 4.1^{\mathrm{d}}$ & $0.83 \pm 2.20^{\mathrm{ab}}$ \\
Mancozeb & $9.4 \pm 3.1^{\mathrm{bc}}$ & $0.09 \pm 0.16^{\mathrm{a}}$ \\
Water & $11.1 \pm 1.14^{\mathrm{c}}$ & $1.21 \pm 1.50^{\mathrm{b}}$ \\
\hline
\end{tabular}

* Means followed by the same letter are not significantly different $(p<0.05)$ determined by Tukey's multiple test.

Table 3. Effect of natural products on the mycelial growth of A. flavus in tomato fruit during six days of storage.

\begin{tabular}{|c|c|c|c|c|c|}
\hline \multirow[t]{2}{*}{ Treatment } & \multicolumn{5}{|c|}{$\begin{array}{c}\text { Mycelial Growth }\left(\mathrm{cm}^{2} ; x \pm \text { S.D.) }\right. \\
\text { Days of Storage }\end{array}$} \\
\hline & 2 & 3 & 4 & 5 & 6 \\
\hline Citrocover & $0.0 \pm 0.0$ & $0.04 \pm 0.1^{\mathrm{ab} *}$ & $0.07 \pm 0.2^{a}$ & $0.1 \pm 0.5^{\mathrm{a}}$ & $0.2 \pm 0.8^{a b}$ \\
\hline Resinadher & $0.0 \pm 0.0$ & $0.0 \pm 0.0^{\mathrm{a}}$ & $0.0 \pm 0.0^{\mathrm{a}}$ & $0.0 \pm 0.0^{\mathrm{a}}$ & $0.0 \pm 0.0^{\mathrm{a}}$ \\
\hline Chitosan & $0.0 \pm 0.0$ & $0.2 \pm 0.2^{\mathrm{abc}}$ & $0.7 \pm 1.0 \mathrm{bc}$ & $0.9 \pm 1.2^{\mathrm{abc}}$ & $1.0 \pm 1.3^{\mathrm{abc}}$ \\
\hline Chitosan coating & $0.0 \pm 0.0$ & $0.2 \pm 0.2^{b c}$ & $0.3 \pm 0.2^{\mathrm{abc}}$ & $0.4 \pm 0.2^{\mathrm{ab}}$ & $1.2 \pm 0.9^{a b c}$ \\
\hline Chitosan nanoparticles & $0.0 \pm 0.0$ & $0.2 \pm 0.3^{b c}$ & $0.3 \pm 0.3^{a b}$ & $0.4 \pm 0.4^{\mathrm{a}}$ & $1.5 \pm 1.5^{b c}$ \\
\hline Mancozeb & $0.0 \pm 0.0$ & $0.3 \pm 0.2^{c}$ & $0.0 \pm 0.5^{\mathrm{c}}$ & $1.3 \pm 0.9 \mathrm{bc}$ & $1.3 \pm 1.9^{b c}$ \\
\hline Water & $0.0 \pm 0.0$ & $0.1 \pm 0.2^{\mathrm{abc}}$ & $0.6 \pm 0.5^{b c}$ & $1.8 \pm 1.8^{c}$ & $1.9 \pm 1.8^{\mathrm{c}}$ \\
\hline
\end{tabular}

* Means followed by the same letter are not significantly different $(p<0.05)$ determined by Tukey's multiple test.

The chemical treatment with Mancozeb was the one that showed the highest incidence $(100 \%)$ of the disease at the end of the six days of storage. Both commercial products notably controlled the infection during the whole storage period of tomato (Resinadher $=1000$; Citrocover $=95 \%$; Figure 1 ).

In general, all the treated fruit showed a significant $(p<0.05)$ decrease in the production of aflatoxins compared to the untreated fruit. The fruit with the lowest values of aflatoxin production were those where Resinadher, Citrocover, and chitosan $(0.95,1.77$, and 1.87, respectively; Table 4) were applied.

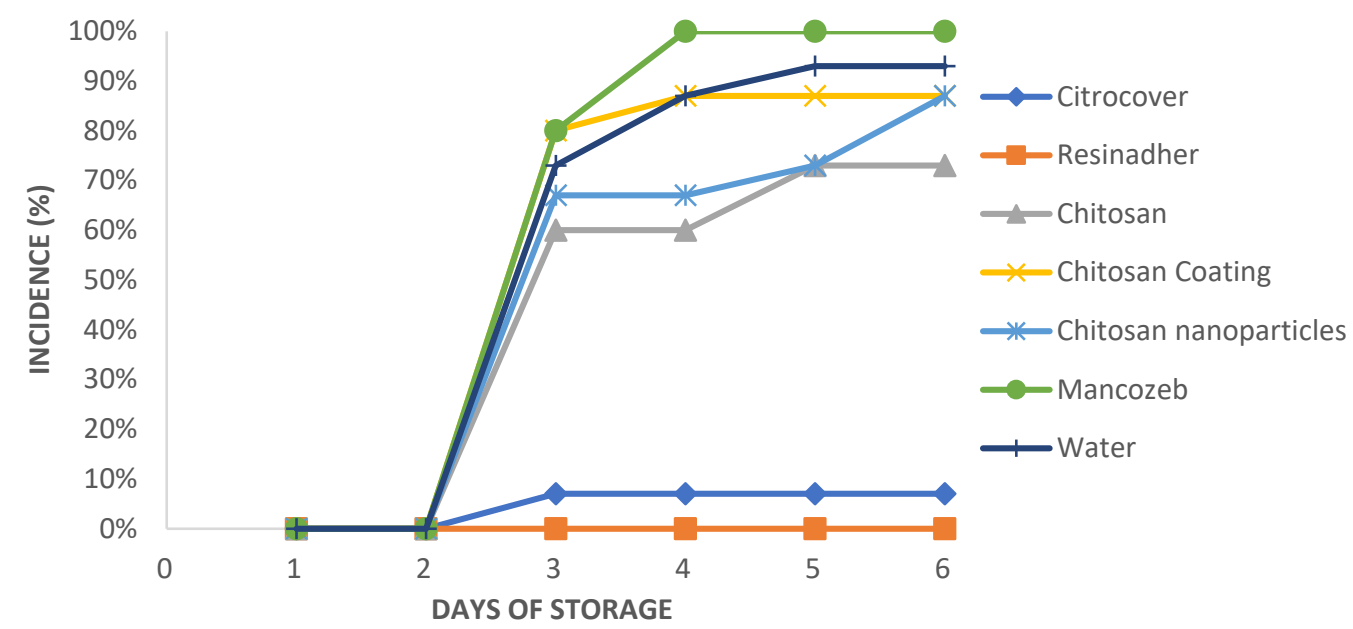

Figure 1. Incidence of A. flavus on tomato fruit treated with different natural products during six days of storage. 
Table 4. Effect of natural products in the production of the aflatoxins of A. flavus-treated tomato after six days of storage.

\begin{tabular}{cc}
\hline Treatment & Aflatoxins (ppb) \\
\hline Citrocover & $1.77 \pm 0.21^{\mathrm{a} *}$ \\
Resinadher & $0.95 \pm 0.68^{\mathrm{a}}$ \\
Chitosan & $2.12 \pm 0.09^{\mathrm{a}}$ \\
Chitosan coating & $2.50 \pm 0.89^{\mathrm{a}}$ \\
Chitosan nanoparticles & $1.87 \pm 0.45^{\mathrm{a}}$ \\
Mancozeb & $1.93 \pm 0.65^{\mathrm{a}}$ \\
Water & $5.00 \pm 0.89^{\mathrm{b}}$ \\
\hline
\end{tabular}

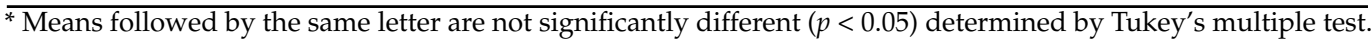

\section{Discussion}

\subsection{In Vitro}

The Citrocover treatment showed the greatest control on A. flavus during in vitro incubation. These results agree with Iglesias' [16] findings. The author evaluated the extracts of in vitro studies of Citrus aurantium, C. latifolia, and C. reticulata on Alternaria solani and Passalora fulva, and reported that, in general, all extracts achieved a notable inhibition of the fungi greater than $50 \%$. The citrus extracts are rich in bioactive compounds such as ascorbic acid, flavonoids, phenolic compounds, anthocyanins, pectins, alkaloids, glycosylases, saponins, steroids, and tannins, among others. Flavonoids and phenols are the main compounds that present a defense against phytopathogenic fungi [17]. Due to their aromatic structure and hydroxyl group, they alter the enzymatic activities of chitinase, chitin synthase, and $\beta$-glucanase of the cytoplasmic membrane of microorganisms [18].

In the Petri plates containing the chitosan coating, no production of aflatoxins (0.0) from the fungus $A$. flavus was recorded. Our data agree with the findings of CortesHigareda et al. [13]. These authors evaluated, in vitro, a chitosan coating at $1 \%$ and reported a complete inhibition of aflatoxin production. This could be due to the fact that chitosan is capable of adsorbing aflatoxin AfB1 when the positive charges of its amino group interact with the negative charges of the oxygen atoms of the aflatoxins [19]. Barkai-Golan [20] mentioned that the zinc present in the environment where the fungi develop stimulates the production of aflatoxins in A. flavus and A. parasiticus. Additionally, it has been reported that chitosan acts in the chelation of zinc; therefore, the addition of chitosan to the medium causes an inhibition in the production of the aflatoxins of the fungus [21]. Chitosan also presents a mechanism that involves ion chelation and for this, it requires the $-\mathrm{OH}$ and $-\mathrm{O}$ groups of the D-glucossamine residues as binders, as well as two or more amino groups of the same chain to join the same ion [22].

\subsection{In Situ}

In this study, the citrus seed extract and pine resin extract notably controlled the mycelial growth and incidence of $A$. flavus in tomato. On the same line, Gaviria-Hernández [23] evaluated the commercial extracts of $C$. sinensis and C. grandis $(0.05 \%)$ on the development of Colletotrichum gloeosporioides and C. acutatum in blackberry and reported a 100\% inhibition in both mycelial growth and fungal biomass with these extracts. Additionally, Silva [24] applied 1\% citrus extracts to control Penicillium spp. in apple and reported a disease control of c.s. $99.5 \%$. The effectiveness of citrus extracts against fungi is due to the presence of high concentrations of phenolic compounds and flavonoids such as flavones and flavone glycosides, which are enzyme inhibitors that affect the fungal respiration in the same way that they have the ability to form both alcohols and esters that inhibit the growth of hyphae as well as prevent the germination of spores.

Data provided by the manufacturer indicate that Citrocover is made up of ascorbic acid, palmitic acid, mannitose, glucose, glycerides, fatty acids, amino acids, citric bioflavonoids mixed with groups of amines, tocopherols, and orange terpenes. There are several researchers that indicate that orange terpenes have fungicidal activities. For ex- 
ample, Quintana-Obregón et al. [25] reported a 100\% inhibition of the mycelial growth of A. tenuissima, but when they added $1 \%$ orange terpene, a $20 \%$ less fungal germination was obtained. The terpenes are compounds that reduce cell division abd inhibit oxygen consumption, mitochondrial respiration, oxidative forsphorylation, and DNA synthesis. The D-limonene specifically increases the fluidity of fungal membranes, leading to a high non-specific permeability of the membrane and loss of integrity, while the antifungal activity of citronellol is attributed to the inhibition of ergorestrol synthesis in the fungal membrane, which results in osmotic and metabolic instability [26]. To date, there are evaluations of commercial products that are citrus-based extracts which have been tested on fungi such as Penicillium spp., C. gloeosporioides, Cladosporium sp., R. stolonifer, Lasiodiplodia theobromae, Phomopsis sp., and Alternaria sp. Additionally, in other agricultural commodities such as apple, papaya, and passion fruit, some commercial products have shown a good control of these fungi [24,27]; however, others have shown limitations in its effect [28]. In the case of Citrocover, fungal growth inhibition, a decrease of sporulation, and a low production of aflatoxins were observed, therefore, it could be an alternative for future use as a biofungicide.

In the same way, the pine resin had an effect on the control of $A$. flavus development. This information agrees with that reported by Schultz [29]. The author evaluated the antimicrobial activity of Pinus occidentalis resin derivatives from a colophony resinous extract and turpentine essential oil. The colophony extract was effective against Microsporum canes, Microsporum gypsium, Trichophyton rubum, and Pseudomonas aeruginosa, while the essential oil of turpentine was effective against $M$. canes, M. gypsium, Candida albicans, and P. aeruginosa. The resin is a mixture of resin acids $(60-75 \%)$, terpenes $(10-15 \%)$, and other components such as alcohols and esters. Colophony and turpentine are the most common resins that are present in pine resin and are attributed to the ability of protecting against microorganisms $[29,30]$. The antimicrobial and antifungal activities of colophony have been attributed to the presence of hydroxyl groups, aldehyde, and ketones [31]. Turpentine has antiseptic properties; is rich in terpenes and terpenoids; is composed mainly of alpha pinene (87.1-94.1\%), beta pinene, and 3 carene; and contains other terpenes such as limonene, pharesen, borneol, camphene, terinolene, and methylcarvinol. The reported antimicrobial activity suggests that the mechanism of action is through interactions between terpenes, altering the enzymatic system related to the energy production and synthesis of structural components within the microorganism [32].

The use of commercial products based on citrus seed extract (Citrocover) and pine resin extract (Resinadher) could be a viable alternative to reduce the development of A. flavus and its production of aflatoxins in tomato fruit.

\section{Materials and Methods}

\subsection{Fungal Strain}

The A. flavus fungus was obtained from the fungal collection of the Laboratory of Postharvest Technology of Agricultural Products at CEPROBI-IPN. The strain was activated on tomato fruit where mycelia and conidia were collected and incubated on Czapeck-dox agar medium at $20^{\circ} \mathrm{C}$.

\subsection{Materials}

The tomato Saladette type was obtained from an orchard located in Tetela del Volcán, México (10 $53^{\prime} 35^{\prime \prime} \mathrm{N} 98^{\circ} 43^{\prime} 47^{\prime \prime}$ O). The medium molecular weight of chitosan (SigmaAldrich, CAS: 9012-76-4; deacetylation degree of 75-85\%) was used for the chitosan coating and nanoparticles synthesis. Glycerol was bought to J.T. Baker. The glacial acetic acid was purchased from Fermont Chemicals Inc. The citrus seed extract (Citrocover) and pine resine extract (Resinadher) were obtained from MS Agros S.A de C. V. Citrocover is C. limon and C. sinensis-based. The extraction of the plant material was carried out by steam distillation. Subsequently, the extracted material was mixed with inert diluents at a concentration of $7 \%$. Resinadher products are pine resin-based and were obtained from P. teocote. The resin 
was collected manually and cleaned as well as later mixed with inert materials and diluents at a concentration of $60 \%$.

\subsection{Treatments Preparation}

Seven treatments were evaluated: (1) chitosan 1\%; (2) chitosan coating $1 \%$; (3) chitosan nanoparticles $0.05 \%$; (4) citrus seed extract (Citrocover) $1 \%$; (5) pine resin extract (Resinadher) $0.5 \%$; (6) chemical fungi (Mancozeb); and (7) water.

The chitosan concentration of $1.0 \%$ was prepared by adding the equal amount $(w / v$ 1:100) of acetic acid to chitosan. The mixture was added to the total volume of distilled water and stirred overnight at room temperature. The solution was adjusted to $\mathrm{pH} 5.5$ with $1 \mathrm{~N} \mathrm{NaOH}$ solution [13]. For the chitosan coating, $0.3 \%$ glycerol as a plasticizer was added to the previously formulated $1 \%$ chitosan solution. The chitosan nanoparticles were synthesized according to the methodology proposed by Correa-Pacheco et al. [33]. Chitosan of the medium molecular weight was used at a concentration of $0.05 \%(w / v)$ and dissolved in both glacial acetic acid $(1 \% v / v)$ and distilled water. In total, $2.5 \mathrm{~mL}$ of this chitosan solution was dissolved in methanol $(40 \mathrm{~mL})$ using a peristaltic pump (Bio-Rad, EP-1 Econo Pump, USA) under moderate stirring. The obtained solution was placed in a rotary evaporator (Rotary Evaporator RE 300, BM 500 Water Bath, Yamato CF 300) at $40{ }^{\circ} \mathrm{C}$ and $50 \mathrm{rpm}$. The final volume of the nanoparticles was $2 \mathrm{~mL}$. The zeta potential of the solution was $+21.3 \mathrm{mV} \pm 0.06$. The citrus seed and pine resin extracts as well as the chemical fungicide were diluted in distilled water using the concentrations recommended by the supplier $(1 \%, 0.5 \%$, and $2 \%$, respectively).

\subsection{Application of the Treatments In Vitro and on Tomatoe}

In vitro: After Czapeck-dox culture medium solidification, $1.0 \mathrm{~mL}$ of $A$. flavus spore solution $\left(10^{5}\right.$ spore $\left.\mathrm{mL}^{-1}\right)$ was added and uniformly dispersed on Petri plates. A $0.5 \mathrm{~cm}$ hole was made in the center of the Petri dish and $20 \mu \mathrm{L}$ of each treatment was added in the hole. Petri dishes were stored for 7 days at $28+2{ }^{\circ} \mathrm{C}$. The inhibition halo of the fungus was measured every day in each treatment with a Truper vernier caliper during 7 days of incubation. Ten Petri plates were used per treatment. Fungal sporulation was evaluated at the end of the experiment using three randomly selected plates from each treatment. The conidia suspension was obtained by adding $10 \mathrm{~mL}$ of distilled water to the Petri dishes and the conidia concentration was calculated using a Neubauer chamber [34].

In situ: Tomato fruit were washed with $1 \%$ sodium hypochlorite and rinsed with sterile distilled water. The fruit were immersed in the treatments for $30 \mathrm{~s}$ and dried at room temperature. A wound was made in the fruit with a sterile dissection needle ( $2 \mathrm{~mm}$ deep) and $20 \mu \mathrm{L}$ of a spore solution of $A$. flavus $\left(10^{5}\right.$ spores $\left.\mathrm{mL}^{-1}\right)$ was added; the fruit were stored at room temperature $\left(28{ }^{\circ} \mathrm{C} \pm 2{ }^{\circ} \mathrm{C}\right)$ for 6 days. Ten fruit were used per treatment [14]. The incidence (\%), mycelial growth (cm), and aflatoxin production (ppb) of A. flavus in tomato were evaluated at the end of storage.

\subsection{Aflatoxin Production by A. flavus}

For the quantification of aflatoxins, the Raptor Neogen (USA) equipment and the Reveal Q+ for the aflatoxin kit were used. Reveal Q+ for aflatoxin is a single-step lateral flow immunoassay and the Raptor ${ }^{\circledR}$ Integrated platform is a lateral flow test strip reader with built-in incubation.

In vitro: At the end of the storage, $10 \mathrm{~mL}$ of sterile distilled water was added to each Petri dish to obtain a solution. Additionally, $50 \mathrm{~mL}$ of $65 \%$ ethanol was added and mixed in an Oster (Mexico) food processor for $30 \mathrm{~s}$ at 10,000 RPM.; furthermore, $2 \mathrm{~mL}$ of this solution was taken and placed in Eppendorf tubes, as well as centrifuged at 12,500 RPM for $1 \mathrm{~min}$. Subsequently, $100 \mu \mathrm{L}$ of the supernatant was taken and $500 \mu \mathrm{L}$ of developer liquid was added and mixed. Finally, $400 \mu \mathrm{L}$ of this solution was taken and placed in the Neogen raptor equipment for reading. 
In situ: at the end of the storage, the fruit were crushed. In total, $10 \mathrm{~g}$ of the sample was taken and $50 \mathrm{~mL}$ of ethanol was added; the procedure described in the previous paragraph was followed.

\subsection{Statistical Analysis}

The treatments were organized in a completely randomized design. Mean and standard deviations were calculated. The in vitro and in situ variables (mycelial growth, sporulation, and aflatoxin content) were subjected to ANOVA and a comparison of the means by Tukey's test at $p<0.05$ was conducted.

\section{Conclusions}

Citrus seed and pine resin extracts effectively inhibited the mycelial growth of $A$. flavus and aflatoxin production, while the chitosan coating reduced only the aflatoxin production. The commercial products Citrocover and Resinadher based on citrus seed and pine resin extracts could be viable alternatives for the control of the fungus A. flavus on tomato.

Author Contributions: M.A.S.-P.: methodology. Z.N.C.-P.: validation and formal analysis. M.L.C.-R.: methodology and formal analysis. O.C.M.-R.: methodology and data curation. D.A.S.-P.: investigation and data curation. M.d.L.R.-G.: investigation and writing-review, editing, and resources. S.B.-B.: conceptualization and writing-review and editing. All authors have read and agreed to the published version of the manuscript.

Funding: We are grateful to CONACYT for funding the student scholarship of Mario Alberto Segura Palacios and for financing project number 316090.

Institutional Review Board Statement: CONACYT project number 316090.

Informed Consent Statement: Not applicable.

Data Availability Statement: Not applicable.

Conflicts of Interest: The authors declare no conflict of interest.

\section{References}

1. Arrúa, A.A.; Moura, J.; Fernandez, D.; Cazal, C. Aspergillus y micotoxinas. Rev. UN Med. 2013, 2, 141-169.

2. Guzman, D. La exposición a la aflatoxina B1 en animales de laboratorio y su significado en la salud pública. Salud Pública Méx. 2007, 49, 227-235.

3. Urrego, J.R.; Días, G.J. Aflatoxinas: Mecanismos de toxicidad en la etiología de cáncer hepático celular. Rev. Fac. Med. 2006, 54, 108-116.

4. Orozco, N.; Montes de Oca, J.H.; Parada, S.; Tlazola, R.Y.; Jiménez, S.A.; Reynoso, J.; Lopez, L.; Hernandez, I.; Ruvalcaba, J.C. The ingestion of aflatoxigenic foods and their possible implications with cervical cancer. J. Negat. No Posit. Results 2019, 4, 130-140.

5. Buchanan, J.R.; Sommer, N.F.; Fortlage, R.J. Aspergillus flavus infection and aflatoxin production in fig fruits. Appl. Microbiol. 1975, 30, 238-241. [CrossRef] [PubMed]

6. Baiyewu, R.A.; Amusa, N.A.; Ayoola, O.A.; Babalola, O.O. Survey of the post harvest diseases and aflatoxin contamination of marketed pawpaw fruit (Carica papaya L.) in South Western Nigeria. Afr. J. Agric. Res. 2007, 24, 178-181.

7. Mariutti, L.R.; Valente, L.M. Survey of aflatoxins in tomato products. Ciênc. Tecnol. Aliment. 2009, 29, 431-434. [CrossRef]

8. Ortega, E.G.; Carrera, M.A.; Delgadillo, D.; Intriago, M.P.; Lares, E.F.; Escorza, Q. Asociación de la exposición ocupacional a plaguicidas organofosforados con el daño oxidativo y actividad de acetilcolinesterasa. Rev. Toxicol. 2016, 33, 39-43.

9. Singh, A.; Singla, A.; Kamboj, P.; Singh, J. Pesticide residues in food grains, vegetables and fruits: A hazard to human health J. Med. Chem. Toxicol. 2017, 2, 1-7.

10. De Ancos, B.; González-Peña, D.; Colina-Coca, C.; Sánchez-Moreno, C. Uso de películas/recubrimientos comestibles en los productos de IV y V gama. Rev. Iberoam. De Tecnol. Postcosech 2015, 16, 8-17.

11. Do Nascimento, F.J.; Diniz, E.T.; de Mesquita, L.X.; de Oliveira, A.M.; Costa, T.F. Extractos vegetales en el control de plagas. Rev. Verde Agroecol. Desenvolv. Sustentável 2008, 3, 1-5.

12. Guédez, C.; Cañizalaez, L.; Avendaño, L.; Scorza, J.; Castillo, C.; Olivar, R.; Méndez, Y.; Sánchez, L. Actividad antifúngica del aceite esencial de naranja (Citrus sinensis L.) sobre hongos postcosecha en frutos de lechosa (Carica papaya L.). Rev. Soc. Ven. Microbiol. 2014, 34, 81-85. 
13. Cortes-Higareda, M.; Ramos-García, M.L.; Correa-Pacheco, Z.; Del Rio, J.C.; Bautista-Baños, S. Nanostructured chitosan/propolis formulations: Characterization and effect on the growth of Aspergillus flavus and production of aflatoxins. Heliyon 2019, 5 , e01776. [CrossRef]

14. Aparicio-García, P.F.; Ventura-Aguilar, R.I.; Del Rio, J.C.; Hernandez-Lopez, M.; Guillen-Sanchez, D.; Salazar-Piña, D.A.; RamosGarcía, M.L.; Bautista-Baños, S. Edible chitosan/propolis coatings and their effect on ripening, development of Aspergillus flavus, and sensory quality in fig fruit, during controlled storage. Plants 2021, 10, 112. [CrossRef]

15. Gonzalez-Andrade, C.; Ramos-García, M.L. Efecto de Productos Naturales Nanoestructurados Sobre el Desarrollo de Aspergillus flavus In Vitro en Maíz (zea mays L.). XXII Congreso Internacional \& XLVII Congreso Nacional de la Sociedad Mexicana de Fitopatología. 2020. Suplemento de la Revista Mexicana de Fitopatología. 100p. Available online: https://www.smf.org.mx/ rmf/suplemento/suplemento382020/Resumenes_Posters.pdf (accessed on 10 October 2021).

16. Iglesias, D. Actividad Antifúngica In Vitro de Extractos Hidroalcohólicos de Hojas de Citrus spp. Frente a Hongos Fitopatogenos de Lycopersicum esculentum Mill. Licenciatura en Agronomía. Universidad Central “Marta Abreu” de Las Villas. Facultad de Ciencias Agropecuarias. Departamento de Biología. Santa Clara, Cuba. 2012. Available online: https://dspace.uclv.edu. cu/bitstream/handle/123456789/1859/Dianella\%20Iglesias\%20HOJAS\%20DE\%20CITRUS.pdf?sequence=1\&isAllowed=y (accessed on 10 October 2021).

17. Ramírez, Y. Actividad Antifúngica In Vivo de Extractos de Citrus reticulata Blanco y Citrus aurantiifolia (Chrisrm.) Swingle Frente a Passarola fulva (Cooke) U. Braun\&Crous. Licenciatura en Agronomía, Universidad Central "Marta Abreu" de las Villas. Santa Clara, Cuba. 2013. Available online: https://dspace.uclv.edu.cu/bitstream/handle/123456789/1817/A0019.pdf? sequence $=1 \&$ isAllowed $=y$ (accessed on 5 October 2021).

18. Amini, M.N.; Safaie, M.J. Antifungal activity of three medicinal plant essential oils against some phytopathogenic fungi. Trakia J. Sci. 2012, 10, 1-8.

19. Juarez-Morales, L.A.; Hernandez-Cocoletzi, H.; Chigo-Anona, E.; Aguila-Almanza, E.; Tenorio-Arvide, G. Chitosan-aflatoxins B1, M1 interaction: A computational approach. Curr. Org. Chem. 2017, 21, 2877-2883. [CrossRef]

20. Barkai-Golan, R. Aspergillus Mycotoxins. In Mycotoxins in Fruits and Vegetables; Barkai-Golan, R., Paster, N., Eds.; Academic Press: Cambridge, MA, USA; Elsevier: Amsterdam, The Netherlands, 2008; pp. 115-151.

21. Klich, M. Environmental and developmental factors influencing aflatoxin production by Aspergillus flavus and Aspergillus parasiticus. Mycosciencie 2007, 48, 71-80. [CrossRef]

22. Montero-Álvarez, J.A.; Paredes-Bautista, M.J.; Rivera-Morales, M.C. Utilización de quitosana para la remoción de arsénico (As) del agua. Superf. Vacío 2010, 23, 136-139.

23. Gavira-Hernández, V.; Patiño-Hoyos, L.F.; Saldarriaga-Cardona, A. Evaluación in vitro de fungicidas comerciales para el control de Colletotrichum spp., in blackberry. Cienc. Tecnol. Agropecu. 2013, 14, 67-75. [CrossRef]

24. Silva, M.E.; Schwan-Estrada, K.R.F.; Balbi-Peña, M.I.; Terumi, A.; Clemente, E.; Stangarlin, J.R. Control del moho azul en poscosecha de manzana con productos naturales. Idesia 2015, 33, 57-63. [CrossRef]

25. Quintana-Obregón, E.A.; Sánchez-Mariñez, R.I.; Cortez-Rocha, M.O.; González-Aguilar, G.A. Actividad antifúngica in vitro de mezcla de terpenos de naranja contra Alternaria tenuissima. Rev. Mex. Mic. 2017, 45, 7-12. [CrossRef]

26. Barroso, A.K.; Ochoa, F.Y.; Cerna, E.; Toruch, M.; Olalde, P.V.; Robles, Y.L. Manejo un vitro de antracnosis (Colletotrichium acutatum Simmonds) en aguacate mediante el uso de principios activos botánicos. Ecosistemas Recur. Agropecu. 2021, 8, e3038.

27. Perera, S.D.; Pérez, E.; Hernandez, J.; Lobo, G.; López- Cepero, J.; Puerta, M.; Torres, J.M.; Lopez, C. Evaluación de la Eficacia de Fungicidas Naturales y Químicos en el Control de Enfermedades Postcosecha Sobre Distintas Variedades de Papaya (II). Cabildo Insular de Tenerife, COAGISORA, COPLACA, Instituto Canario de Investigaciones Agrarias ICIA. 2010. Available online: https:/ / www.agrocabildo.org/publica/Publicaciones/subt_336_papaya.pdf (accessed on 10 October 2021).

28. Benato, E.A.; Sigris, J.M.M.; Hanashiro, M.M.; Magalhães, M.J.M.; Binotti, C.S. Avaliação de fungicidas e produtos alternativos no controle de podridões pós-colheita em maracujá amarelo. Summa Phytopathol. 2002, 28, 299-304.

29. Schultz, C.W. Potencial Antimicótico y Antibacterial In Vitro de la Colofonia y la Tremetina, Derivados de la Resina Oleosa de la Conífera Endémica Pinus Occidentalis, en el Municipio de Jarabacoa, Provincia La Vega. Licenciado en Farmacia, Universidad Nacional Pedro Henríquez Ureña Facultad de Ciencias de la Salud, Santo Domingo, Republica Dominicana. 2014. Available online: https: / / repositorio.unphu.edu.do/handle/123456789/1007 (accessed on 4 October 2021).

30. Gallo, J.A.; Sarria, R.A. Obtención de colofonia y trementina a partir de resina de pino de la especia patula y posterior evaluación de los parámetros de calidad. Jou. Cie. Ing. 2013, 5, 88-91.

31. Pavón, C.P. Material Para Impresión 2D Basado en Resinas Naturales de Colofonia. Master en Ingeniería, Procesado y Caracterización de Materiales., Universidad Politécnica de Valencia. Valencia, España. 2019. Available online: https: / / riunet.upv.es/bitstream/handle/10251/125974/Pav\%C3\%B3n\%20-\%20Material\%20para\%20impresion\%203D\% 20basado\%20en \%20resinas\%20naturales\%20de\%20colofonia.pdf?sequence=1 (accessed on 5 October 2021).

32. Amri, I.; Gargouri, S.; Hamrouni, L.; Hanana, M.; Fezzani, T.; Jamoussi, B. Chemical composition, phytotoxic and antifungical activities of Pinus pinea essential oil. J. Pest Sci. 2012, 85, 199-207. [CrossRef] 
33. Correa-Pacheco, Z.N.; Bautista-Baños, S.; Valle-Marquina, M.A.; Hernandez-Lopez, M. The effect of nanostructured chitosan and chitosan-thyme essential oil coatings on Colletotrichum gloeosporioides growth in vitro and on cv Hass avocado and fruit quality. J. Phytopathol. 2017, 165, 297-305. [CrossRef]

34. Cia, P.; Pascholati, S.; Benato, E.; Camili, E.; Santos, A. Effects of gamma and UV-C irradiation on the postharvest control of papaya anthracnose. Postharvest Biol. Technol. 2007, 43, 366-373. [CrossRef] 